\title{
The effects of renal sympathetic denervation in the left atrium enlargement after pulmonary vein isolation
}

\author{
Márcio Galindo Kiuchi' ${ }^{1,3}$, Shaojie Chen ${ }^{2,3}$, Luis Marcelo Rodrigues Paz ${ }^{1}$ and Helmut Pürerfellner ${ }^{3}$ \\ ${ }^{1}$ Department of Medicine, Division of Artificial Cardiac Stimulation, Hospital e Clínica São Gonçalo, São Gonçalo, RJ, Brazil \\ ${ }^{2}$ Department of Cardiology, Shanghai First People's Hospital, Shanghai Jiao Tong University School of Medicine, Shanghai, China \\ ${ }^{3}$ Department of Cardiology, Elisabethinen University Teaching Hospital Linz, Linz, Austria
}

\begin{abstract}
Background: Atrial fibrillation (AF) disturbs around 2\% of people worldwide, and this percentage will increase in the next 50 years. Recently a study reported that renal sympathetic denervation (RSD) reduces AF recurrences when combined with pulmonary vein isolation (PVI).

Methods: We aim to evaluate the impact of RSD in patients underwent PVI previously due paroxysmal AF (PAF) in the left atrium (LA) progression of the diameter and volume rates evaluated by the transthoracic echocardiography. We enrolled 85 patients, identified in our offices, with PAF that undergone PVI, who were followed during 1 year, being the AF recurrence, reported. At the $12^{\text {th }}$ month of monitoring, we analyzed the data retrospectively, and 2 groups were created: Non $A F$ recurrence $(n=53)$ and $A F$ recurrence $(n=32)$. At this time point, sixteen individuals aleatory underwent RSD (seven from non AF recurrence group and nine from AF recurrence group) and were followed for 6 months ( $18^{\text {th }}$ month of monitoring). The other 69 subjects were just observed during the same period.
\end{abstract}

Results: The LA growth rate/month for non RSD group was $0.83 \pm 0.44$ and $0.22 \pm 1.16 \mathrm{~mm} / \mathrm{month}$ for the RSD group (P<0.0001), and LA distension rate/month for non RSD group was $3.43 \pm 0.94$ and $2.20 \pm 2.71 \mathrm{~mL} / \mathrm{m}^{2} / \mathrm{month}$ for the RSD group $(\mathrm{P}<0.0001)$.

Conclusion: Our results show that the RSD effects independently the AF recurrence, the LA growth rate/month and the LA distension rate/month for non RSD group were significantly higher than for the RSD group.

\begin{abstract}
Abbreviations: ABPM: ambulatory blood pressure measurements; AF: atrial fibrillation; BP: blood pressure; $\Delta$ : variation; eGFR: estimated glomerular filtration rate; LA: left atrium; LVEF: left ventricular ejection fraction; PAF: paroxysmal atrial fibrillation; PVI: pulmonary vein isolation; RSD: renal sympathetic denervation
\end{abstract}

\section{Introduction}

Atrial fibrillation (AF) affects approximately $2 \%$ of the population worldwide, and this percentage will increase in the next 50 years $[1,2]$. The perfect tactic for the handling of AF is rhythm control, but this is sometimes very hard to accomplish [3]. Pokushalov and colleagues [4] in recent times described that renal sympathetic denervation (RSD) reduces AF recurrences when joined with pulmonary vein isolation (PVI). Pointing of the pulmonary veins (PVs) and/or the PV antrum is the keystone for best AF ablation procedures. If the PVs are under fire, whole electrical PVI should be the aim of the process. For such procedures, total electrical split-up of all PVs is presently extensively established as the top endpoint. An approach using the percutaneous catheter-based distribution of radiofrequency energy was freshly settled to interrupt the sympathetic renal innervation. This procedure wide-open no severe vascular or renal technical hitches in the long term (up to 36 months). The aim of this study was to assesss the impact of RSD in patients underwent PVI previously due paroxysmal AF (PAF) in the left atrium (LA) progression of the diameter and volume rates evaluated by the transthoracic echocardiography.

\section{Materials and methods}

\section{Study design}

This study was piloted at the Department of Cardiac Artificial Stimulation and Cardiac Surgery of the Hospital e Clínica São Gonçalo, São Gonçalo, Rio de Janeiro, Brazil in partnership with Elisabethinen Krankenhaus, Linz, Austria. A cohort of patients received pulmonary vein isolation for AF treatment.

Patients were followed for one year and a half after the implant procedure. Inclusion criteria were as follows: (i) mean 24-hour systolic ambulatory blood pressure measurements (ABPM) of $\geq 100$ and $<130$ $\mathrm{mmHg}$, (ii) essential hypertension for more than a year. Hypertension is defined as office blood pressure (BP) values $\geq 140 \mathrm{mmHg}$ systolic $\mathrm{BP}$ and/or $\geq 90 \mathrm{mmHg}$ diastolic $\mathrm{BP}$, based on the confirmation from randomized controlled trials that in subjectss with these BP values

Correspondence to: Márcio Galindo Kiuchi, MD, MSc, PhD, Division of Cardiac Surgery and Artificial Cardiac Stimulation, Department of Medicine, Hospital e Clínica São Gonçalo, Rua Cel. Moreira César, 138 - Centro, São Gonçalo, Rio de Janeiro 24440-400, Brazil, Tel/Fax: +55 (21) 26047744; E-mail: marciokiuchi@ gmail.com

Key words: atrial fibrillation; echocardiogram; left atrium; pulmonary vein isolation; renal sympathetic denervation.

Received: June 12, 2017; Accepted: July 28, 2017; Published: July 31, 2017 
treatment-induced BP diminutions are advantageous or as mean 24-hour ABPM $\geq 130 \mathrm{mmHg}$ for systolic $\mathrm{BP}$ and/or $\geq 80 \mathrm{mmHg}$ for diastolic BP [21], (iii) age between 18 and 80 years; (iv) structurally normal heart to cardiac magnetic resonance, myocardial scintigraphy or coronary angiography, without ischemia, fibrosis area or any other disease; (v) a physically normal heart with an ejection fraction of $>50 \%$ as measured by echocardiography (Simpson's method), (vi) patients underwent PVI due to paroxysmal AF (PAF, well-defined as AF events lasting $<7$ days with spontaneous termination, and (vii) the capability to read, understand, and sign the informed consent term, as well attend the clinical tests.

Exclusion criteria were: (i) pregnancy; (ii) valvular sickness with substantial adversative sequelae; (iii) unstable angina, myocardial infarction, transitory ischemic attack or stroke within the 6 months previously the procedure; (iv) renovascular anomalies; (v) psychiatric illness; (vi) allergy to ionic contrast; (vii) the inability to be followed clinically; (viii) a known addiction to substances that disturbs the intellect; (ix) congestive heart failure into functional class II to IV symptoms in acordance to New York Heart Association; and (xi) a transverse left atrial diameter (LAD) $>55 \mathrm{~mm}$ on transthoracic echocardiography.

The enrollment of the participants began in January 2013 and ended in June 2015. We enrolled 85 patients, identified in our offices, with PAF that undergone PVI, who were followed during 1 year, being the AF recurrence, reported. At the $12^{\text {th }}$ month of monitoring, we analyzed the data retrospectively, and 2 groups were created: Non AF recurrence $(n=53)$ and AF recurrence $(n=32)$. At this time point, sixteen individuals aleatory underwent RSD (seven from non AF recurrence group and nine from AF recurrence group) and were followed for 6 months ( $18^{\text {th }}$ month of monitoring). The other 69 subjects were just observed during the same period. The study was shepherded in accordance with the Declaration of Helsinki and was permitted by the Ethics Committee of our hospital. All individuals delivered written informed consent before inclusion in the investigation. This study was blind, the clinician responsible for follow-up and other parameter assessments, was not aware of whether RSD had been performed.

\section{Twenty-four hour Holter monitoring, twenty-four hour} ABPM, and transthoracic echocardiography

These procedures were previously reported in detail by our group [22].

\section{Pulmonary vein isolation and renal sympathetic denervation}

These procedures were reported in detail previously by other manuscripts $[6,22,23]$.

\section{Follow-up patients}

The patients were evaluated quarterly after PVI to observe AF recurrence or not, by physical examination in the office, electrocardiogram, 24-hour Holter monitoring, and transthoracic echocardiogram, during one year. From $12^{\text {th }}$ to $18^{\text {th }}$ month, the subjects were evaluated quarterly by physical examination in the office and semiannually by transthoracic echocardiogram. All patients that required anticoagulation were using dabigatran at 150 or $110 \mathrm{mg}$ twice a day, according to the recommendation. The patients were considered anticoagulated owing to the profile and mechanism of action of this new anticoagulant.

\section{Statistical analysis}

All individuals enrolled were comprised in the analysis. The results were expressed as the mean and standard deviation (mean \pm SD) in the case of normal distribution and as median with interquartile range otherwise. Statistical tests were all of two sides. Comparisons between the two paired values were performed by paired t-test in case of a Gaussian distribution or alternatively, by Wilcoxon test. The comparisons between more than two values paired values were performed by analysis of variance for repeated measures ANOVA or Kruskal-Wallis test, as appropriate, complemented by a post hoc test. Frequencies were compared with $x^{2}$ or Fisher's exact tests. $\mathrm{P}$ values $<0.05$ were considered significant. Correlations between two variables were performed by Pearson in the case of a Gaussian distribution or, alternatively, with the Spearman correlation test. All statistical analyzes were performed using the program Graphpad Prism v 7.0 (Graphpad software, La Jolla, CA, USA).

\section{Results}

\section{Patients}

The 85 individuals who had all the inclusion criteria were comprised in the evaluation. The baseline features divided by AF recurrence or not, into two groups, are meticulously displayed in Table 1. From these 85 patients, 53 (62\%) did not develop a new PAF onset after PVI, while 32 subjects (38\%) presented AF recurrence during the 12 months of monitoring.

\section{Echocardiographic parameters}

One year of follow-up (from baseline to $12^{\text {th }}$ month): At baseline, we can observe that the difference of LA diameter from subjects that did not present AF recurrence is lower than in those ones that AF recurred, as shown in Table 2 . We also can see that LA variation $(\Delta)$ growth at each 6 months is different between the $6^{\text {th }}$ and the $12^{\text {th }}$ months for both groups, but did not differ between groups. However, the LA growth rate per month did not differ between groups. The same was observed regarding the difference of indexed LA volume from subjects that did not present $\mathrm{AF}$ recurrence, showing lower LA volume, that those ones that AF recurred, as shown in Table 2. The indexed LA volume also increased along the time in comparison to baseline values, into the same group. The LA $\Delta$ distension at each 6 months is different between the $6^{\text {th }}$ and the $12^{\text {th }}$ months only for the group whom AF recurred. And, the LA growth distension rate per month did not differ between groups.

Six months of follow-up (from RSD at $12^{\text {th }}$ month till $18^{\text {th }}$ month): Table 3 shows even some patients had undergone RSD in AF recurrence group the LA diameter at the $18^{\text {th }}$ month of monitoring is still higher than that observed in the $12^{\text {th }}$ month, into the same group, and higher than the LA diameter presented by non AF recurrence group at the end of follow-up. The LA $\Delta$ growth at each 6 months is slower at the $18^{\text {th }}$ month compared to the $12^{\text {th }}$ month for both groups but did not differ between groups. However, at the end of monitoring the LA growth rate per month is slower just in the AF recurrence group in comparison to $12^{\text {th }}$ month, but did not differ between groups. Table 3 also shows that the indexed LA volume did not change in comparison to $12^{\text {th }}$ month, but was different between groups. The LA $\Delta$ distension at each 6 months is slower between the $18^{\text {th }}$ and the $12^{\text {th }}$ months for both groups. And finally, the LA growth distension rate per month at the end of follow-up, in comparison to $12^{\text {th }}$ month, was slower only in the AF recurrence group.

\section{RSD effects measurements}

Evaluating the RSD effects independently the AF recurrence, we evaluated 69 patients that did not submit to the procedure, and 16 subjects underwent RSD. At baseline, $6^{\text {th }}, 12^{\text {th }}$, and $18^{\text {th }}$ month of 
Table 1. Baseline features

\begin{tabular}{|c|c|c|c|c|}
\hline Parameters & Overall & Non AF recurrence & AF recurrence & P value \\
\hline $\mathrm{N}$ & 85 & 53 & 32 & --- \\
\hline Age, years & $54.11 \pm 7.80$ & $53.58 \pm 7.47$ & $54.97 \pm 8.36$ & 0.4311 \\
\hline Body mass index, $\mathrm{kg} / \mathrm{m}^{2}$ & $26.92 \pm 1.75$ & $26.79 \pm 1.86$ & $27.13 \pm 1.56$ & 0.4003 \\
\hline Male gender (\%) & $62(73 \%)$ & $35(66 \%)$ & $27(84 \%)$ & 0.0807 \\
\hline White ethnicity (\%) & $62(73 \%)$ & $42(79 \%)$ & $20(63 \%)$ & 0.1304 \\
\hline Type 2 Diabetes Mellitus & $26(31 \%)$ & $17(32 \%)$ & $9(28 \%)$ & 0.8099 \\
\hline Creatinine, mg/dL & $0.95 \pm 0.08$ & $0.93 \pm 0.11$ & $0.98 \pm 0.09$ & 0.0330 \\
\hline $\mathrm{eGFR}, \mathrm{mL} / \mathrm{min} / 1.73 \mathrm{~m}^{2}$ & $89.82 \pm 8.47$ & $92.53 \pm 9.45$ & $88.70 \pm 6.97$ & 0.0350 \\
\hline Albumin:creatinine ratio, mg/g & $18.76 \pm 8.19$ & $18.30 \pm 7.70$ & $19.53 \pm 9.03$ & 0.5060 \\
\hline \multicolumn{5}{|l|}{ Antihypertensive } \\
\hline ACE-inhibitors/ARB & $85(100 \%)$ & $53(100 \%)$ & $32(100 \%)$ & $>0.9999$ \\
\hline Diuretics & $85(100 \%)$ & $53(100 \%)$ & $32(100 \%)$ & $>0.9999$ \\
\hline DHP Ca ${ }^{++}$channel blockers & $17(20 \%)$ & $10(19 \%)$ & $7(22 \%)$ & 0.7837 \\
\hline$\beta$-blockers & $85(100 \%)$ & $53(100 \%)$ & $32(100 \%)$ & $>0.9999$ \\
\hline Mean 24-hour ABPM, mmHg & $117 \pm 5 / 70 \pm 4$ & $116 \pm 5 / 69 \pm 4$ & $117 \pm 6 / 71 \pm 5$ & $0.6168 / 0.3834$ \\
\hline
\end{tabular}

Table 2. Left atrium evaluation during one year of follow-up.

\begin{tabular}{|c|c|c|c|c|c|c|c|c|c|}
\hline & Overall & $\begin{array}{c}\text { Non AF } \\
\text { recurrence }\end{array}$ & AF recurrence & Overall & $\begin{array}{c}\text { Non AF } \\
\text { recurrence }\end{array}$ & AF recurrence & Overall & $\begin{array}{c}\text { Non AF } \\
\text { recurrence }\end{array}$ & AF recurrence \\
\hline & \multicolumn{3}{|c|}{ Baseline } & \multicolumn{3}{|c|}{$6^{\text {th }}$ month } & \multicolumn{3}{|c|}{$12^{\text {th }}$ month } \\
\hline $\mathrm{N}$ & 85 & 53 & 32 & 85 & 53 & 32 & 85 & 53 & 32 \\
\hline LA diameter, $\mathrm{mm}$ & $45.94 \pm 3.59$ & $44.08 \pm 2.26$ & $49.03 \pm 3.26^{\dagger}$ & $47.35 \pm 3.54$ & $45.48 \pm 2.21$ & $50.43 \pm 3.17^{\dagger}$ & $49.03 \pm 3.26^{* *}$ & $46.07 \pm 2.23^{*}$ & $51.05 \pm 3.16^{\dagger}$ \\
\hline$\Delta$ LA growth, $\mathrm{mm} / 6$ months & --- & --- & --- & $1.41 \pm 0.20$ & $1.41 \pm 0.19$ & $1.40 \pm 0.22$ & $0.60 \pm 0.14^{++}+$ & $0.59 \pm 0.14^{+++}$ & $0.62 \pm 0.13^{+++}$ \\
\hline LA growth rate, $\mathrm{mm} / \mathrm{month}$ & --- & --- & --- & --- & --- & --- & $0.08 \pm 0.04$ & $0.08 \pm 0.03$ & $0.08 \pm 0.04$ \\
\hline Indexed LA volume, $\mathrm{mL} / \mathrm{m}^{2}$ & $40.59 \pm 5.30$ & $37.89 \pm 2.67$ & $45.06 \pm 5.58^{\dagger}$ & $44.55 \pm 5.30^{* * *}$ & $41.87 \pm 2.74^{* *}$ & $48.98 \pm 5.57^{* \dagger}$ & $48.70 \pm 5.32^{* * * *}$ & $46.01 \pm 2.78^{* * * *}$ & $53.18 \pm 5.53^{* * * \dagger}$ \\
\hline$\Delta$ LA distension, $\mathrm{mL} / \mathrm{m}^{2} / 6$ months & --- & & --- & $3.96 \pm 0.37$ & $3.99 \pm 0.39$ & $3.91 \pm 0.33$ & $4.16 \pm 0.26^{++}$ & $4.13 \pm 0.23$ & $4.20 \pm 0.31^{+}$ \\
\hline LA distension rate, $\mathrm{mL} / \mathrm{m}^{2} /$ month & --- & --- & --- & --- & --- & --- & $0.34 \pm 0.03$ & $0.34 \pm 0.03$ & $0.35 \pm 0.04$ \\
\hline
\end{tabular}

Values are presented as mean $\pm \mathrm{SD}$. ${ }^{* * *} \mathrm{P}<0.0001,{ }^{* *} \mathrm{P}<0.001,{ }^{*} \mathrm{P}<0.05$ vs. baseline value into the same group; ${ }^{\dagger} \mathrm{P}<0.0001$ for non $\mathrm{AF} v s$. AF recurrence at the same time point; ${ }^{+} \mathrm{P}<0.05$,

${ }^{++} \mathrm{P}<0.001,{ }^{++} \mathrm{P}<0.0001$ for $6^{\text {th }} v s .12^{\text {th }}$ recurrence into the same group. AF, atrial fibrillation; LA, left atrium.

Table 3. Left atrium evaluation after renal sympathetic denervation during 6 months of follow-up.

\begin{tabular}{|c|c|c|c|}
\hline & Overall & Non AF recurrence & AF recurrence \\
\hline & \multicolumn{3}{|c|}{$18^{\text {th }}$ month $\left(6^{\text {th }}\right.$ month after renal sympathetic denervation performance $)$} \\
\hline $\mathrm{N}$ & 85 & 53 & 32 \\
\hline LA diameter, $\mathrm{mm}$ & $48.09 \pm 3.74$ & $46.34 \pm 2.48$ & $50.99 \pm 3.70^{* * *+}$ \\
\hline$\Delta$ LA growth, $\mathrm{mm} / 6$ months & $0.14 \pm 0.72^{* * *}$ & $0.26 \pm 0.63^{*}$ & $0.07 \pm 0.76^{* * * *}$ \\
\hline LA growth rate, $\mathrm{mm} / \mathrm{month}$ & $0.02 \pm 0.12^{* *}$ & $0.04 \pm 0.11$ & $0.01 \pm 0.13^{*}$ \\
\hline Indexed LA volume, $\mathrm{mL} / \mathrm{m}^{2}$ & $50.18 \pm 5.75$ & $47.71 \pm 3.45$ & $54.28 \pm 6.47^{\dagger}$ \\
\hline$\Delta \mathrm{LA}$ distension, $\mathrm{mL} / \mathrm{m}^{2} / 6$ months & $1.48 \pm 1.51^{* * *}$ & $1.70 \pm 1.34^{* * *}$ & $1.10 \pm 1.72^{* * * *}$ \\
\hline LA distension rate, $\mathrm{mL} / \mathrm{m}^{2} /$ month & $0.25 \pm 0.25^{*}$ & $0.28 \pm 0.22$ & $0.18 \pm 0.29^{*}$ \\
\hline
\end{tabular}

Values are presented as mean $\pm \mathrm{SD} .{ }^{* * *} \mathrm{P}<0.0001,{ }^{* *} \mathrm{P}<0.001,{ }^{*} \mathrm{P}<0.05 v s .12^{\text {th }}$ month value into the same group; ${ }^{\dagger} \mathrm{P}<0.0001$ for non $\mathrm{AF} v s . \mathrm{AF}$ recurrence at the $18^{\text {th }}$ month of follow-up; AF, atrial fibrillation; LA, left atrium.

monitoring the non RSD group presented the mean LA diameter of $46.28 \pm 3.59,47.69 \pm 3.54,48.29 \pm 3.56$ ( $\mathrm{P}=0.0187$ vs. baseline $)$, and $48.77 \pm 3.52 \mathrm{~mm}(\mathrm{P}=0.0010$ vs. baseline), respectively, as well as the RSD group, presented the mean LA diameter of $44.50 \pm 3.37,45.88 \pm 3.22$, $46.48 \pm 3.26$, and $45.15 \pm 3.29 \mathrm{~mm}$, respectively. The only significant difference between groups was found in the $18^{\text {th }}$ month $(\mathrm{P}=0.0056)$, as shown in Figure 1A. The LA $\Delta$ growth at each 6 months at the $6^{\text {th }}, 12^{\text {th }}$ and $18^{\text {th }}$ month in the non RSD group was $1.41 \pm 0.19,0.60 \pm 0.14$, and $0.48 \pm 0.14 \mathrm{~mm} / 6$ months, respectively $\left(\mathrm{P}<0.0001\right.$ for $18^{\text {th }}$ and $12^{\text {th }} v s .6^{\text {th }}$ month, and $18^{\text {th }} v s$. $12^{\text {th }}$ month), and in the RSD group was $1.38 \pm 0.25$, $0.60 \pm 0.15$, and $-1.33 \pm 0.12 \mathrm{~mm} / 6$ months, respectively $(\mathrm{P}<0.0001$ for $18^{\text {th }}$ and $12^{\text {th }} v s .6^{\text {th }}$ month, and $18^{\text {th }} v s .12^{\text {th }}$ month). At the $18^{\text {th }}$ month the comparison between groups was significant $(\mathrm{P}<0.0001)$, as shown in Figure 1B. The LA growth rate for non RSD group was $0.83 \pm 0.44$ and $0.22 \pm 1.16 \mathrm{~mm} / \mathrm{month}$ for the RSD group $(\mathrm{P}<0.0001)$, as shown in Figure 1C.
At baseline, $6^{\text {th }}, 12^{\text {th }}$, and $18^{\text {th }}$ month of monitoring the non RSD group presented the mean LA volume of $41.01 \pm 5.30,44.99 \pm 5.31$, $49.12 \pm 5.32$, and $51.30 \pm 5.35 \mathrm{~mL} / \mathrm{m}^{2} \quad(\mathrm{P}<0.0001$ vs. baseline values $)$, respectively, as well as the RSD group, presented the mean LA volume of $38.75 \pm 5.07,42.65 \pm 4.96,46.90 \pm 5.08$, and $45.34 \pm 4.94 \mathrm{~mL} /$ $\mathrm{m}^{2}$, respectively. The only significant difference between groups was found in the $18^{\text {th }}$ month $(\mathrm{P}=0.0014)$, as shown in Figure $2 \mathrm{~A}$. The LA $\Delta$ distension rate at each 6 months at the $6^{\text {th }}, 12^{\text {th }}$ and $18^{\text {th }}$ month in the non RSD group was $3.97 \pm 0.35,4.14 \pm 0.27$, and $2.18 \pm 0.33 \mathrm{~mL} / \mathrm{m}^{2} / 6$ months, respectively $\left(\mathrm{P}=0.0330\right.$ for $12^{\text {th }} v s$. $6^{\text {th }}$ month, $\mathrm{P}<0.0001$ for $18^{\text {th }} v s .6^{\text {th }}$ month, and $18^{\text {th }} v s .12^{\text {th }}$ month), and in the RSD group was $3.90 \pm 0.44,4.25 \pm 0.24$, and $-1.56 \pm 0.34 \mathrm{~mL} / \mathrm{m}^{2} / 6$ months, respectively $\left(\mathrm{P}=0.0299\right.$ for $12^{\text {th }} v s .6^{\text {th }}$ month, $\mathrm{P}<0.0001$ for $18^{\text {th }} v s .6^{\text {th }}$ month, and $18^{\text {th }} v s .12^{\text {th }}$ month). At the $18^{\text {th }}$ month the comparison between groups was significant $(\mathrm{P}<0.0001)$, as shown in Figure $2 \mathrm{~B}$. The LA distension 
(A)

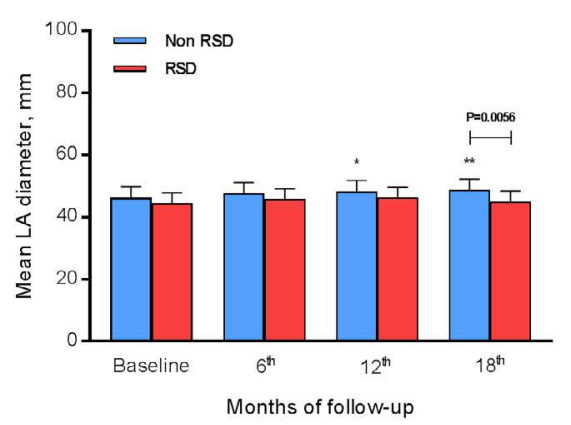

(B)

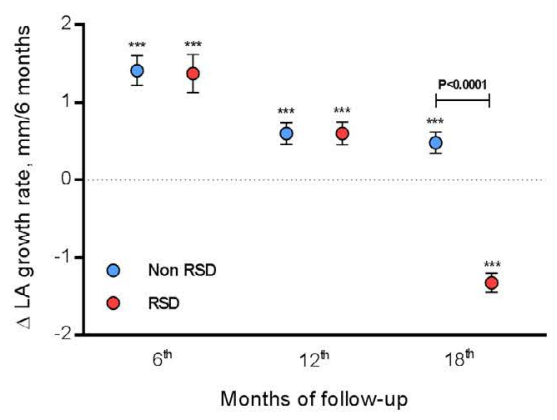

(C)

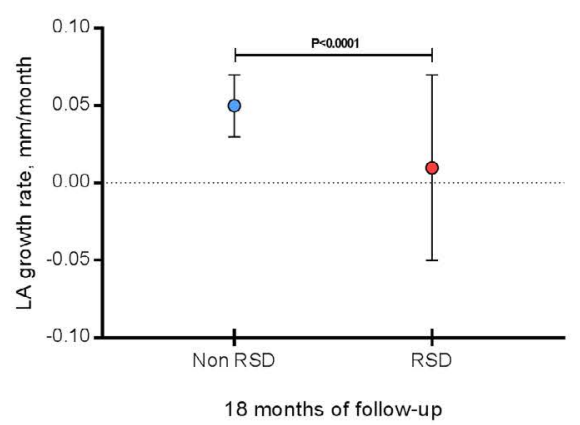

Figure 1: Evaluating the RSD effects independently the AF recurrence, we assessed 69 patients that did not submit to the procedure and 16 subjects underwent RSD. Monitoring of LA diameter (A), LA $\Delta$ (variation) growth at each 6 months (B), and LA growth rate/month (C) was done at baseline, $6^{\text {th }}, 12^{\text {th }}$ and $18^{\text {th }}$ month of follow-up; AF, atrial fibrillation; LA, left atrium.

(A)

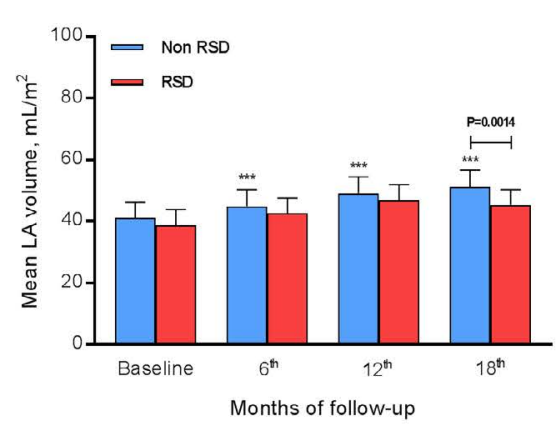

(B)

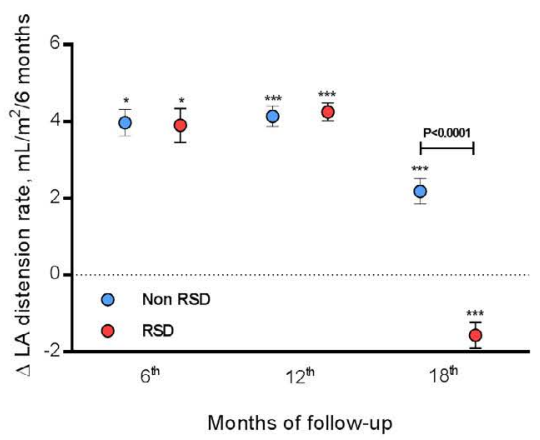

(C)

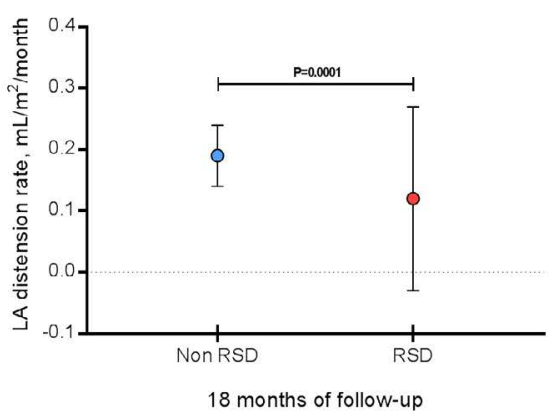

Figure 2: Evaluating the RSD effects independently the AF recurrence, we assessed 69 patients that did not submit to the procedure and 16 subjects underwent RSD. Monitoring of LA volume (A), LA $\Delta$ (variation) distension at each 6 months (B), and LA distension rate/month (C) was done at baseline, $6^{\text {th }}, 12^{\text {th }}$ and $18^{\text {th }}$ month of follow-up; AF, atrial fibrillation; LA, left atrium.

rate for non RSD group was $3.43 \pm 0.94$ and $2.20 \pm 2.71 \mathrm{~mL} / \mathrm{m}^{2} / \mathrm{month}$ for the RSD group $(\mathrm{P}<0.0001)$, as shown in Figure 2C.

\section{Discussion}

In the present study, we demonstrate that $\mathrm{AF}$ recurrence is higher in patients underwent PVI (38\%) during 12 months of monitoring. We calculated the estimated glomerular filtration rate (eGFR) using the CKD-EPI equation, which is known to perform better for a larger range of GFR values [5]. The adopted protocol [6] for denervation involved the delivery of a higher number of ablative lesions per artery than in previous studies $[7,8]$ and an irrigated catheter with the more wide contact area. Sympathetic activation is a trademark of the essential hypertensive state happening early in the clinical course of the disease, even in the controlled patients [9-11]. The mechanisms of the hyperadrenergic state are manifold and include reflex and neurohumoral pathways $[9,10,12]$. The adrenergic activation has an opposing influence on cardiovascular morbidity and, in the case of renal failure, also on cardiovascular mortality $[9,10,13,14]$. We believe that this overactivity from the essential hypertensive state is in part contained by anti-hypertensive agents because patients sustain a normotensive state. The break of this vicious feedback cycle, which diminishes this sympathetic overactivity and the feedback of the renin-angiotensin-aldosterone-system-loop [15], may at least in part explain our findings regarding the impact of RSD in the progression of the LA diameter and volume rates evaluated by the transthoracic echocardiography. Angiotensin II can upsurge atrial pressure, supporter atrial fibrosis, and modify ion channels, all of which are involved in atrial organizational and electrical altering resulting in AF [16]. Polymorphisms in mechanisms of this pathway have been connected to the progress of AF [17]. The expression of angiotensinconverting enzymes is augmented in the atria during $\mathrm{AF}$ [16], and management with angiotensin converting enzyme inhibitor, as well as, angiotensin receptor blocker decreases the ocurrence of AF [18].

The association of RSD with PVI had an encouraging effect on AF recurrence. Once PVI was achieved, the prevailing originating source was eradicated. As the patients in our study were controlled hypertensive individuals, we believe that in the subjects without $\mathrm{CKD}$ we reached the reduction of the sympathetic and the feedback loop of the renin-angiotensin-aldosterone system. An engorged atrial dimension modifies the electro-anatomic substrate with the existence of augmented non-uniform anisotropy and a conduction disruption, which could promote AF [19]. Fibrosis in the LA has a vital role in defining the changing aspects of $\mathrm{AF}$, which could exist as a newscaster for reentrant paths and change wavefront promulgation, causing fractionated electrograms, wavebreaks, and conduction intervals [20].

Evaluating LA behavior during 1 year, the LA growth rate per month did not differ between groups, as well as, the difference of indexed LA volume from subjects that did not present AF recurrence, showing lower LA volume, that those ones that AF recurred. The LA $\Delta$ distension at each 6 months is different between the $6^{\text {th }}$ and the $12^{\text {th }}$ months only for the group whom AF recurred. The LA $\Delta$ distension at each 6 months is different between the $6^{\text {th }}$ and the $12^{\text {th }}$ months only for the group whom AF recurred. Some patients had undergone RSD 
in AF recurrence group showed the LA diameter at the $18^{\text {th }}$ month of monitoring still higher than that observed in the $12^{\text {th }}$ month, into the same group, and higher than the LA diameter presented by non AF recurrence group at the end of follow-up. However, at the end of monitoring the LA growth rate per month is slower just in the AF recurrence group in comparison to $12^{\text {th }}$ month, but did not differ between groups. The indexed LA volume did not change in comparison to $12^{\text {th }}$ month but was different between groups. The LA $\Delta$ distension at each 6 months is slower between the $18^{\text {th }}$ and the $12^{\text {th }}$ months for both groups. And finally, the LA growth distension rate per month at the end of follow-up, in comparison to $12^{\text {th }}$ month, was slower only in the AF recurrence group [21-23].

Evaluating the RSD effects independently the AF recurrence, we evaluated 69 patients that did not submit to the procedure, and 16 subjects underwent RSD. Regarding the LA growth rate at each 6 months, the only significant difference between groups was found in the $18^{\text {th }}$ month of monitoring, showing slower growth in those ones underwent RSD. The LA growth rate/month for non RSD group was significantly higher than for the RSD group. The RSD group presented the mean LA volume significant different between groups at the $18^{\text {th }}$ month $(\mathrm{P}=0.0014)$, and the LA $\Delta$ distension rate at each 6 months at in the non RSD group was higher in comparison to RSD group at the $18^{\text {th }}$ month of monitoring $(\mathrm{P}<0.0001)$. The LA distension rate/month for non RSD group was higher than for the RSD group $(\mathrm{P}<0.0001)$.

\section{Conclusion}

Our results show that the LA growth rate/month and the LA distension rate/month are slower in $\mathrm{AF}$ recurrence group, at least in part, because it comprises some patients had undergone RSD. Moreover, evaluating the RSD effects independently the AF recurrence, the LA growth rate/month and the LA distension rate/month for non RSD group were significantly higher than for the RSD group.

\section{Author contributions}

$\checkmark$ Conception and design of the research: Márcio Galindo Kiuchi, Shaojie Chen, and Helmut Pürerfellner

$\checkmark$ Procedures: Márcio Galindo Kiuchi

$\checkmark$ Acquisition of data: Luis Marcelo Rodrigues Paz

$\checkmark$ Analysis and interpretation of the data: Shaojie Chen and Márcio Galindo Kiuchi

$\checkmark$ Statistical analysis: Márcio Galindo Kiuchi

$\checkmark$ Obtaining funding: Márcio Galindo Kiuchi and Luis Marcelo Rodrigues $\mathrm{Paz}$

$\checkmark$ Drafting of the manuscript: Márcio Galindo Kiuchi, Shaojie Chen, and Helmut Pürerfellner

$\checkmark$ Critical revision of the manuscript for significant intellectual content: Márcio Galindo Kiuchi, Shaojie Chen, and Helmut Pürerfellner

$\checkmark$ Supervision: Helmut Pürerfellner

\section{Conflict of interests}

All the authors declare no conflict of interest.

\section{Acknowledgement}

The authors thank all participants of this study and Pacemed by technical support.

\section{Funding}

The study was sponsored by health plans in the state of Rio de Janeiro and the Pacemed (US\$300,000).

\section{References}

1. Stewart S, Hart CL, Hole DJ, McMurray JJ (2001) Population prevalence, incidence, and predictors of atrial fibrillation in the Renfrew/Paisley study. Heart 86: 516-521. [Crossref]

2. Go AS, Hylek EM, Phillips KA, Chang Y, Henault LE, et al. (2001) Prevalence of diagnosed atrial fibrillation in adults: national implications for rhythm management and stroke prevention: the AnTicoagulation and Risk Factors in Atrial Fibrillation (ATRIA) Study. JAMA 285: 2370-2375. [Crossref]

3. European Heart Rhythm Association, European Association for Cardio-Thoracic Surgery, Camm AJ, Kirchhof P, Lip GY, et al. (2010) Guidelines for the management of atrial fibrillation: the Task Force for the Management of Atrial Fibrillation of the European Society of Cardiology (ESC). Eur Heart J 31: 2369-2429. [Crossref]

4. Pokushalov E, Romanov A, Corbucci G, Artyomenko S, Baranova V, et al. (2012) A randomized comparison of pulmonary vein isolation with versus without concomitant renal artery denervation in patients with refractory symptomatic atrial fibrillation and resistant hypertension. J Am Coll Cardiol ;60: 1163-1170. [Crossref]

5. Levey AS, Stevens LA, Schmid CH, Zhang YL, Castro AF III, et al. (2009) CKD-EPI (Chronic Kidney Disease Epidemiology Collaboration): A new equation to estimate glomerular filtration rate. Ann Intern Med 150: 604-612. [Crossref]

6. Kiuchi MG, Maia GL, de Queiroz Carreira MA, Kiuchi T, Chen S, et al. (2013) Effects of renal denervation with a standard irrigated cardiac ablation catheter on blood pressure and renal function in patients with chronic kidney disease and resistant hypertension. Eur Heart J 34: 2114-2121. [Crossref]

7. Krum H, Schlaich M, Whitbourn R, Sobotka PA, Sadowski J, Bartus K, et al. (2009) Catheter-based renal sympathetic denervation for resistant hypertension: a multicenter safety and proof-of-principle cohort study. Lancet 373: 1275-1281. [Crossref]

8. Symplicity HTN-1 Investigators (2011) Catheter-based renal sympathetic denervation for resistant hypertension: durability of blood pressure reduction out to 24 months. Hypertension 57: 911-917. [Crossref]

9. Grassi G (2010) Sympathetic neural activity in hypertension and related diseases. Am J Hypertens 23:1052-1060. [Crossref]

10. Grassi G (2009) Assessment of sympathetic cardiovascular drive in human hypertension: achievements and perspectives. Hypertension 54: 690-697. [Crossref]

11. Paton JF, Raizada MK (2010) Neurogenic hypertension. Exp Physiol 95: 569-571. [Crossref]

12. McGrath BP, Ledingham JG, Benedict CR (1978) Catecholamines in peripheral venous plasma in patients on chronic haemodialysis. Clin Sci Mol Med 55: 89-96. [Crossref]

13. Grassi G, Bertolli S, Seravalle G (2012) Sympathetic nervous system: role in hypertension and in chronic kidney disease. Curr Opin Nephrol Hypertens 21: 46-51. [Crossref]

14. Zoccali C, Mallamaci F, Parlongo S, Cutrupi S, Benedetto FA, et al. (2002) Plasma norepinephrine predicts survival and incident cardiovascular events in patients with end stage renal disease. Circulation 105: 1354-1359. [Crossref]

15. Wang L, Lu CZ, Zhang X, Luo D, Zhao B, et al. (2013) The effect of catheter based renal sympathetic denervation on renin-angiotensin-aldosterone system in patients with resistant hypertension. Zhonghua Xin Xue Guan Bing Za Zhi 41: 3-7. [Crossref]

16. Goette A, Staack T, Röcken C, Arndt M, Geller JC, et al. (2000) Increased expression of extracellular signal-regulated kinase and angiotensin-converting enzyme in human atria during atrial fibrillation. J Am Coll Cardiol 35: 1669-1677. [Crossref]

17. Tsai CT, Lai LP, Lin JL, Chiang FT, Hwang JJ, et al. (2004) Renin-angiotensin system gene polymorphisms and atrial fibrillation. Circulation 109: 1640-1646. [Crossref]

18. Wachtell K, Lehto M, Gerdts E, Olsen MH, Hornestam B,et al. (2005) Angiotensin II receptor blockade reduces new-onset atrial fibrillation and subsequent stroke compared to atenolol: the Losartan Intervention For End Point Reduction in Hypertension (LIFE) study. J Am Coll Cardiol 45: 712-719. [Crossref]

19. Sanders P, Morton JB, Davidson NC, Spence SJ, Vohra JK, et al. (2003) Electrical remodeling of the atria in congestive heart failure: electrophysiological and electroanatomic mapping in humans. Circulation 108: 1461-1468. [Crossref] 
20. Tanaka K, Zlochiver S, Vikstrom KL, Yamazaki M, Moreno J, et al. (2007) Spatial distribution of fibrosis governs fibrillation wave dynamics in the posterior left atrium during heart failure. Circ Res 101: 839-847. [Crossref]

21. Mancia G, Fagard R, Narkiewicz K, Redon J, Zanchetti A, et al. (2013) 2013 ESH/ ESC guidelines for the management of arterial hypertension: the Task Force for the Management of Arterial Hypertension of the European Society of Hypertension (ESH) and of the European Society of Cardiology (ESC). Eur Heart J 34: 2159-2219. [Crossref]
22. Kiuchi MG, Chen S, E Silva GR, Rodrigues Paz LM, Kiuchi T, et al. (2017) The addition of renal sympathetic denervation to pulmonary vein isolation reduces recurrence of paroxysmal atrial fibrillation in chronic kidney disease patients. J Interv Card Electrophysiol 48: 215-222. [Crossref]

23. Pokushalov E, Romanov A, Corbucci G, Artyomenko S, Turov A, et al. (2011) Ablation of paroxysmal and persistent atrial fibrillation: 1-year follow-up through continuous subcutaneous monitoring. J Cardiovasc Electrophysiol 22: 369-375. [Crossref]

Copyright: (2017 Kiuchi MG. This is an open-access article distributed under the terms of the Creative Commons Attribution License, which permits unrestricted use, distribution, and reproduction in any medium, provided the original author and source are credited. 